\title{
PENGARUH PENERAPAN FAMILY CENTERED CARE TERHADAP PELAKSANAAN PERSONAL HYGIENE (MEMANDIKAN)
}

\author{
Ageng Abdi Putra ${ }^{1}$, I Gusti Ayu Mirah Adhi ${ }^{2}$, Kasmawati Surianingsih ${ }^{3}$ \\ ${ }^{1,2)}$ Pengajar Sekolah Tinggi Ilmu Kesehatan (STIKES) Mataram \\ ${ }^{3)}$ Perawat RSUD Patuh Patuh Patut Patju Lombok Barat, NTB \\ Email: agenk.putra@yahoo.com
}

\begin{abstract}
ABSTRAK
Kebersihan sangat penting bagi setiap individu. Jika sedang sakit atau dirawat di rumah sakit, kebersihan diri seseorang sering kali terabaikan. Berdasarkan kondisi tersebut saat ini dicanangkan sistem pelayanan yang berpusat pada pasien dan keluarga (patien and family centered care) untuk meningkatkan mutu pelayanan yang berkualitas. Penelitian ini bertujuan untuk mengetahui pengaruh penerapan family centered care terhadap pelaksanaan personal hygiene (memandikan) di ruang rawat inap anak RSUD Patut Patuh Patju Kabupaten Lombok Barat.

Desain penelitian ini adalah pra-eksperimen (one group pretest and post test) dengan jumlah populasi 74 orang. Sampel penelitian diambil menggunakan tehnik accidental sampling dan diperoleh sampel penelitian sebanyak 46 orang. Pengambilan data mengunakan lembar observasi (SPO memandikan pasien dirumah sakit). Analisa data menggunakan uji wilcoxon signed ranks test.

Hasil penelitian menunjukkan pelaksanaan personal hygiene sebelum penerapan family centered care dalam katageri Cukup 11 orang responden dan Kurang 35 orang responden, setelah pelaksanaan personal hygiene terdapat peningkatan keberhasilan yakni tergolong dalam katageri Baik 7 orang responden, katagori Cukup 28 orang responden dan Kurang 11 orang responden.

Kesimpulan dari penelitian ini adalah ada pengaruh penerapan family centered careter hadap pelaksanaan personal hygiene (memandikan) di Ruang Irna Anak. Berdasarkan hasil penelitian ini dapat dilihat juga adanya peningkatan keberhasilan orang tua dari sebelum penerapan family centered care dengan setelah penerapan family centered care tentang personal hygien (memandikan) anaknya selama berada di RS. Berdasarkan hasil penelitian ini diharapkan orang tua menjadi lebih mandiri dan berani ikut serta dalam perawatan anaknya saat sakit, juga dapat menjadi masukan maupun informasi tambahan untuk meningkatkan mutu pelayanan keperawatan.
\end{abstract}

Kata Kunci: Family center care, Personal Hygiene, Memandikan Pasien.

\section{PENDAHULUAN}

\begin{tabular}{llrrrr}
\multicolumn{2}{c}{ Kebutuhan } & dasar & manusia & & Personal hygiene adalah suatu \\
merupakan focus dalam & asuhan & tindakan untuk memelihara kebersihan \\
keperawatan. Bagi pasien yang & dan kesehatan seseorang untuk \\
mengalami gangguan kesehatan & kesejahteraan fisik dan psikis. Kurang \\
kemungkinan ada satu atau beberapa & perawatan diri adalah kondisi dimana \\
kebutuhan dasar pasien yang akan & seseorang tidak mampu melakukan \\
terganggu, salah satunyaa dalah & perawatan kebersihan untuk dirinya (Fitri, \\
pemenuhan kebutuhan dasar manusia & 2014).
\end{tabular}
personal hygiene (Wartonah, 2010). 
Kebersihan sangat dipengaruhi oleh nilai individu dan kebiasaan. Jika seseorang sakit, masalah kebersihan biasanya kurang diperhatikan.

Sistem pelayanan dewasa ini mengutamakan pelayanan berpusat pada pasien dan keluarga (patien and family centered care) untuk memberikan pelayanan yang berkualitas sehingga kesalahan dari tenaga kesehatan dapat di minimalisasi oleh karena itu sangat penting bagi perawat untuk melibatkan keluarga dalamtin dakan keperawatan khususnya personal hygiene (memandikan). Family centered care yaitu dasar pemikiran dalam keperawatan yang digunakan untuk memberikan asuhan keperawatan kepada pasien dengan melibat kankeluarga sebagai focus utama perawatan (Fiane, 2012). Hal ini sejalan dengan penelitian yang dilakukan oleh Arie Kusumaningrum tentang aplikasi dan strategi konsep family centered care pada hospitalisasi anak sekolah, yang menyimpulkan bahwa penerapan family centered care dalam perawatan prasekolah melibatkan semuaa spek dari kebijakan, fasilitas dan perawatan (staf) menjadi satu-satunya sinergi dalam perawatan anak. Proses perubahan dalam perawatan anak melibatkan semua aktivitas perawatan dari prosedur penerimaan pasien, meminimalkan kecemasan perpisahan, meminimalkan injuri dan nyeri, serta pengalaman positif terkait dengan hospitalisasi.

Kontak pertama perawat kepada keluarga dapat melalui anggota keluarga yang sakit. Perawat yang bekerja dengan pasien dan keluarga dirumah sakit bertanggungjawab dalam memberikan perawatan langsung atau mengawasi keluarga memberikan perawatan pada anggota keluarga yang dirawat.

Berdasarkan data dinas kesehatan provinsi NTB rata-rata lama hari rawat atau LOS (length of stay) pada tahun 2016 adalah 3 hari, angka tersebut naik bila dibandingkan nilai LOS tahun 2015 sebesar 2 hari. Sedangkan rata-rata $L O S$ (length of stay) untuk kabupaten Lombok barat adalah 5 hari. Semakin lama hari rawat pasien maka pasien akan semakin tidak nyaman bila selama dirawat pasien tidak pernah dilakukan prosedur tindakan personal hygiene (Dinas Kesehatan NTB, 2017).

Studi awal penelitian pada bulan Agustus 2018 di RSUD Patut Patuh Patju Lombok Barat dengan wawancara 10 keluarga pasien di ruang rawat inap anak yang rata-rata hari rawatnya lebih dari dua hari, 3 keluarga pasien mengatakan takut untuk membersihkan sendiri anaknya yang dirawat, 2 keluarga pasien mengeluh kurang mengerti tentang kebersihan terhadap kesembuhan anaknya dan 5 keluarga pasien menyatakan tidak bisa melakukan personal hygiene karena bagimereka adalah hal yang baru untuk memandikan pasien di atas tempat tidur berbeda dengan tindakan personal hygiene yang lain seperti memotong kuku, sikat gigi dan perawatan muka dapat dilakukan sendiri oleh pasien maupun keluarga di atas tempat tidur tanpa harus mendapatkan pendidikan kesehatan tentang tatalaksana kegiatan tersebut.

Dari hasil wawan cara dengan kepala ruang rawat inap anak di RSUD Patut Patuh Patju Lombok Barat menyatakan bahwa pelaksanaan pemenuhan kebutuhan dasar manusia (personal hygiene) pasien masih belum optimal, hal ini dikarenakan masih banyak tugas pokok perawat yang harus diutamakan dan peralatan untuk melakukan personal hugiene belum memadai serta tidak adanya pendidikan kesehatan untuk keluarga yang menunggu untuk melakukan perawatan bersama khususnya personal hygiene kepada pasien anak yang dirawat. Hal ini sejalan dengan penelitian yang dilakukan oleh Elsy (2014) tentang peran keluarga dalam pemenuhan kebutuhan personal hygiene CVA dengan hasil penelitian yang dilakukan terhadap $52 \%$ berperan buruk 
sehingga perlu untuk memberi pengetahuan kepada keluarga tentang pentingnya pemenuhan kebutuhan personal hygiene oleh keluarga.

Berdasar kan uraian tersebut diatas, maka peneliti tertarik untuk melakukan penelitian tentang pengaruh penerapan family centered care terhadap pelaksanaan personal hygiene (memandikan) pasien di Ruang Rawat Inap Anak RSUD Patut Patuh Patju Lombok Barat.

\section{BAHAN DAN METODE}

Jenis penelitian ini adalah praexperimental dengan rancangan one group pra-post tes design. Populasi yakni seluruh orang tua yang anaknya sedang rawatinap di IRNA Anak. Tehnik pengambilan sampel menggunakan Accidental Sampling. Jumlah sampel sebanyak 46 orang tua.

Kriteria sampel yaitu semua orang tua yang anaknya dirawat lebih dari 1 hari di ruang IRNA Anak.Variabel bebas pada penelitian ini adalah Family Centered Care, pengukuran dengan SOP dan variabel terikat penelitian ini adalah pelaksanaan personal hygiene (memandikan). Penelitian ini dilaku-kan pada tanggal 03 Februari sampai 16 februari 2019. Uji Statistic dalam penelitian ini menggunakan Uji Wilcoxon (Uji Non Parametric).

\section{HASIL}

Tabel 1,Distri busi Jumlah Responden Berdasarkan Umur Dan Jenis Kelamin

\begin{tabular}{|c|l|c|c|}
\hline No & \multicolumn{1}{|c|}{ Variabel } & $\begin{array}{c}\text { Jumlah } \\
\text { (n) }\end{array}$ & $\begin{array}{c}\text { Presentase } \\
(\%)\end{array}$ \\
\hline 1 & Usia & & \\
& $17-25$ tahun & 9 & $19,57 \%$ \\
& $26-35$ tahun & 34 & $73,91 \%$ \\
& $36-45$ tahun & 3 & $6,52 \%$ \\
& Total & 46 & $100 \%$ \\
\hline 2 & Jenis Kelamin & & \\
& Laki-laki & 9 & $19,6 \%$ \\
& Perempuan & 37 & $80,4 \%$ \\
& Total & 46 & $100 \%$ \\
\hline
\end{tabular}

Sumber: Data Primer Penelitian di Ruang IRNA Anak RSUD P3 Tahun 2019
Dari tabel 1, dapat disimpulkan bahwa responden terbanyak pada kategori usia 26-35 tahun yaitu 34 responden (73,91\%), Distribusi responden berdasarkan jenis kelamin yang terbanyak yaitu pada jenis kelamin perempuan sebanyak 37 responden $(80,4 \%)$.

Tabel 2. Distribusi tingkat keberhasilan responden dalam pelaksanaan personal hygien sebelum dilakukan penerapan family centered care.

\begin{tabular}{ccc}
\hline \multicolumn{2}{c}{ KeterampilanF } & $(\%)$ \\
\hline Baik & 0 & $0 \%$ \\
Cukup & 11 & $23,9 \%$ \\
Kurang & 35 & $76,1 \%$ \\
Jumlah & 46 & $100 \%$
\end{tabular}

Sumber: Data Primer Penelitian di Ruang IRNA Anak RSUD P3 Tahun 2019

Dari tabel 2, menunjukkan bahwa tingkat keterampilan terbanyak yaitu pada kategori kurang sebanyak 35 responden $(76,1 \%)$.

Tabel 3 Distribusi tingkat pelaksanaan personal hygiene (memandikan) oleh responden setelah dilakukan penerapan Family centered care.

\begin{tabular}{ccc}
\hline Keterampilan & F & $(\%)$ \\
\hline Baik & 7 & $15,22 \%$ \\
Cukup & 28 & $60,87 \%$ \\
Kurang & 11 & $23,91 \%$ \\
Jumlah & 46 & $100 \%$
\end{tabular}

Sumber: Data Primer Penelitian di Ruang IRNA Anak RSUD P3 Tahun 2019

Dari tabel 3, menunjukkan bahwa tingkat keterampilan terbanyak yaitu pada kategori cukup sebanyak 28 responden $(60,87 \%)$.

Tabel 4, Hasil Uji Wilcoxon

\begin{tabular}{|c|c|c|c|}
\hline & $\mathrm{N}$ & Media min/mak & $\mathrm{P}$ \\
\hline $\begin{array}{l}\text { Sebelum } \\
\text { perlakuan }\end{array}$ & 46 & $18,50(12-25)$ & 0,00 \\
\hline $\begin{array}{l}\text { Sesudah } \\
\text { Perlakuan }\end{array}$ & 46 & $25,00(17-32)$ & \\
\hline
\end{tabular}


Berdasarkan hasil uji statistic menggunakan Wilcoxon didapatkan nilai $\mathrm{p}$ $=0,000(\mathrm{p}<0,05)$, artinya Ho ditolak dan $\mathrm{Ha}$ diterima. Dengan demikian di simpulkan ada pengaruh penerapan family centered care terhadap pelaksanaan personal hygiene (memandikan).

\section{PEMBAHASAN}

Berdasarkan hasil penelitian yang telah dilakukan terhadap 46 responden dengan menggunakan instrument penelitian berupa lembar observasi sebelum dilakukan penerapan family centered care mengenai cara memandikan pasien diperoleh data sebanyak 76,1\% responden dalam kategori kurang, kategori cukup 23,9\% dan tidak ada satupun dalam kategori baik.

$$
\text { Keluarga }
$$

ketidaktahuannya dalam melakukan personal hygiene (memandikan). Sehingga peneliti memberikan penyuluhan tentang personal hygien (memandikan) sesuai SOP RSUD Patut Patuh Patju Lombok Barat. Berdasarkanteori yang di kemukakan oleh Shelton dalam Fiane (2012) keluarga adalah bagian yang konstan merupakan hal yang penting. Fungsi perawat sebagai motivator menghargai dan menghormati peran keluarga dalam merawat pasien serta bertanggung jawab penuh dalam kesehatan pasien. Selain itu, perawat harus mendukung perkembangan sosial dan emosional, serta memenuhi kebutuhan pasien. Oleh karna itu, dalam menjalankan system perawatan kesehatan, keluarga dilibatkan dalam membuat keputusan, mengasuh, mendidik, dan melakukan pembelaan terhadap hak anggota kluarga mereka selama menjalani masa perawatan.

Sebagian besar responden berpendidikan SLTA dan pekerjaan responden yang terbanyak adalah ibu rumah tangga yang dimanasangat minim informasi yang dimiliki tentang memandikan pasien ditempat tidur karena ibu rumah tangga lebih banyak menghabiskan waktu dirumah. Menurut peneliti kemampuan dan kemauan keluarga untuk ikut serta dalam perawatan terhadap anggota keluarganya yang sakit tidak lepas dari informasi dan pengetahuan yang dimiliki.

Penelitian ini sejalan dengan penelitian yang dilakukan oleh Yugistyowati (2015) tentang penerapan Family Centerd Care sebagai program keberhasilan perawatan yang dimana disimpulkan bahwa pendidikan kesehatan pada orang tua pasien dengan perawatan berfokus pada keluarga sebaiknya dilakukan secara berkelanjutan sehingga meningkatkan keterampilan orang tua dalam merawat keluarga atau anaknya.

Berdasarkan hasil uji statistik menggunakan uji Wilcoxon diperoleh nilai $P=0,00(p<0,05)$ sehingga dapat disimpulkan ada pengaruh penerapan family centered care terhadap pelaksanaan personal hygien (memandikan) di ruang irna anak RSUD Patut Patuh Patju Kabupaten Lombok Barat.

Berdasarkan hasil penelitian yang peneliti peroleh dapat dikatakan terjadi perubahan yang cukup signifikan dimana terdapat tingkat keberhasilan responden terhadap penerapan personal hygiene (memandikan) setelah penerapan family centered care sebanyak 15,22\% responden dengan kategori baik dan sebanyak $36,97 \%$ responden dengan katagori cukup. Hal ini didukung oleh teori yang dikemukakan Notoatmodjo (2010) dimana pengetahuan dipengaruhi oleh usia, pendidikan, pekerjaan, pengalaman, serta informasi yang diperoleh sehingga meningkatkan keterampilan seseorang.

Dalam penelitian ini, metode penyuluhan dalam memperkenalkan family center care yang peneliti gunakan mampu diterima cukup baik oleh responden. Keterampilan keluarga dalam membantu memenuhi kebutuhan personal hygiene semakin meningkat, sehingga 
membantu proses perawatan pasien di rumah sakit.

\section{KESIMPULAN}

Ada Pengaruh Penerapan Family Centered Care Terhadap Pelaksanaan Personal Hygiene (Memandikan) Di Ruang Rawat Inap Anak RSUD Patut Patuh Patju Kabupaten Lombok Barat Tahun 2019.

Diharapkan hasil dapat memajukan pelayananan yang lebih optimal dan membantu mempercepat kesembuhan pasien yang sedang di rawat dengan melaksanakan pemenuhan personal hygine melalui pendekatan Family Centerd Care.

\section{DAFTRAR PUSTAKA}

Dinas Kesehatan Provinsi NTB. (2017). Profil Kesehatan Provinsi Nusa Tenggara Barat Tahun 2016. Mataram: Dikes Provinsi NTB.

Elsy. (2014). Peran Keluarga dalam Pemenuhan Kebutuhan Personal Hygiene pada Pasien CVA. Ponorogo: Penelitian Fakultas Ilmu Kesehatan Universitas Muhammadiyah Ponorogo.

Fiane de Fretes. (2012). Hubungan Family Centered Care dengan Efek Hospitalisasi pada Anak. Semarang: Skripsi Ilmu Keperawatan FakultasIlmu Kesehatan Universitas Kristen Satya Wacana Salatiga.

Fitri, Respati A. (2014). Konsep Kebutuhan Dasar Manusia. Yogyakarta: Dua catra offcet.

RSUD Patut Patuh Patju Lombok Barat. (2019). Profil Rumah Sakit Umum Daerah Patut Patuh Patju Lombok Barat.

Wartonah., Tarwoto. (2010). Kebutuhan

Dasar Manusia dan Proses

Keperawatan Edisi Ketiga. Jakarta: Salemba Medika.

Yugistyowati. Anafrin. (2019). Penerapan

Family Centered Care (FCC)

Sebagai Program Keberhasilan

Perawatan Bayi Prematur.

Yogyakarta:JKA 